\title{
Opinion Review \\ Unlearning, Relearning, and Paradigm Shift to Online Tertiary Education during the COVID-19 Pandemic in Bangladesh \\ Salequl Islam
}

\begin{abstract}
The current coronavirus disease 2019 (COVID-19) pandemic has compelled to shut down all levels of educational institutions worldwide for a particular time. The pandemic has forced educators and institutions to rapidly switching from classroom teaching to online teaching. The changes in teaching strategies have led both teachers and students into sudden multifaced challenges. Consequently, Bangladesh has closed down all classroom teaching and adapted online system education using different digital platforms. This opinion review has outlined some challenges and opportunities of online in Bangladesh as a representative of developing countries. This paper has further reviewed underlined vital factors in the university system of developing countries that may contribute to paradigm shifts in the education system in the modern competitive world.
\end{abstract}

Keywords: Unlearning; Relearning; Paradigm shift; COVID-19; Online Education; eWork; Bangladesh.

Bangladesh Journal of Medical Science, Special Issue on COVID-19. 2021. Page : 65-71 DOI: https://doi.org/10.3329/bjms.v20i5.55399

\section{Introduction}

The emergence of the novel coronavirus disease 2019 (COVID-19) caused by the highly contagious severe acute respiratory syndrome coronavirus 2 (SARS-CoV-2) has remodeled the healthcare, education, economic, and social systems worldwide ${ }^{1-3}$. Limited movements, restrictions to movements, additional personal protection measures, social distancing practices have been adopted as potential means to reduce transmission of the virus to the mass population ${ }^{4}$. Certain levels of concerning society have been shown to accept new technologies and communication modalities rapidly ${ }^{5-7}$. Adherence to new modalities varied extensively from country to country and community to community inside a country, depending on national policy, populations' perception, and resources availability. In the meantime, COVID-19 became a pandemic ${ }^{8,9}$. The World Health Organization (WHO) declared the ongoing pandemic of COVID-19 as a global public emergency ${ }^{10}$. As of 27 July 2021, about 300 countries worldwide have reported more than 193 million confirmed cases, led to over 4100,000 deaths ${ }^{11}$. COVID-19 was detected in Bangladesh in the second week of March 2020. Soon after, the Government of Bangladesh closed down all kinds of classroom teaching education from elementary level to university level. After few months, online system education has been introduced using different digital platforms for junior high school, senior high school, and University levels. Therefore, the emergence of COVID-19 in Bangladesh has heavily hindered all levels of education, particularly in the area where hands-on training is imperative. This opinion review will elucidate how COVID-19 emergence has disrupted traditional university education in Bangladesh. It will further outline some challenges and opportunities of online education in Bangladesh as a representative of developing countries.

\section{Administration of the Bangladeshi Education System}

Overall, Education in Bangladesh is monitored by the Ministry of Education (MOE), Bangladesh. It divides sector-wise overseeing responsibilities on various agencies, including the Directorate of Secondary and Higher Education that administer comprehensive activities for secondary and higher secondary level education. The University Grants Commission (UGC) was formed as an autonomous administration body for the country's quality assurance in higher education institutes (HEI),

Correspondence: Dr. Md. Salequl Islam, Professor, Department of Microbiology, Jahangirnagar University, Savar, Dhaka-1342, Bangladesh. Email, salequl@juniv.edu, Orcid ID: http://orcid.org/0000-0001-6131-4132. 
which are public universities ${ }^{12}$. The Bangladeshi UGC is modeled after the British University Grants Committee. This British model was followed in other South Asian countries, formerly part of British India ${ }^{13}$. On the other hand, the Bangladesh government's Primary and Mass Education Ministry solely oversees elementary education and non-formal education programs for children and adults.

\section{Traditional Undergraduate and Master degree Education in Bangladesh}

UGC is an agency that disburses Bangladesh government funds (grants) to public universities. In addition, it coordinates and regulates both public and private universities regarding their compliance to set quality criteria. Undergraduate university education in Bangladesh has been well structured as four years of coursework, followed by some short internship training related to primary subject's working fields. Usually, during the first two years, students learn the fundamental of the significant subject and several supportive extra-departmental associated courses. Universities have adopted different curricula for Bachelor's (Honours) Degree that usually consist of 140-168 credits. The total number of credits of each bachelor program is distributed into theoretical, practical at laboratory, field-work, internship/ industrial training courses, and in viva-voce examination to assess a comprehensive knowledge gain by the students. The whole undergraduate program extends for eight consecutive semesters under four academic years (exceptionally, some departments require 10 semesters for five years) divided into four interlinked parts. One academic year is divided into two consecutive semesters, and examinations are held at the end of each semester. Public universities run their programs following both years- and semester-systems. Most private universities use semester systems, but trimester systems are also standard at private universities. The Master's degree courses under most Bangladeshi Universities remain over one academic year under two consecutive semesters. The master's degree course is divided into two groups: general Group and thesis Group. Students under the thesis group are supposed to conduct some capstone research project under a mentorship of a faculty from the respective or related department.

Bangladesh's higher education system has affiliated smaller teaching institutions called colleges under Bangladesh's National University (NU) to provide tertiary-level education. However, not all NU- affiliated colleges teach the full range of bachelor's or master's degree programs, much smaller than universities. The Bangladesh Open University (BOU) offers diploma, bachelor's, and master's programs via distance education. The colleges under NU and BOU bear some low reputation of building quality education compared with full universities. Many colleges only offer upper-secondary (higher secondary school certificate, HSC) level education 12,13 .

\section{COVID-19 Pandemic, eWork, Online Education, and Distant learning}

COVID-19 was first identified in Wuhan, China, in December 2019. By 27th July 2021, there were 193.7 million cases and over 4154,600 deaths worldwide, with an aggressive case fatality ratio (CFR) among confirmed cases ${ }^{11}$. The first reported cases for COVID-19 in Bangladesh were detected in early March ${ }^{14,15}$, and by $6^{\text {th }}$ August 2021, there were over 1,335,260 confirmed cases with 22,150 deaths giving a CFR of $1.65 \%{ }^{16}$. However, there are possibilities of underreporting COVID-19 cases in Bangladesh due to resources, healthcare personnel, and facilities ${ }^{17}$. As WHO forecasted SARS-CoV2 as a highly contagious virus, countries all over the world imposed different levels of movement restrictions in the name of complete or partial lockdowns, social distancing regulations, and state of emergency ${ }^{4,10}$.

Along with many countries, the Bangladesh government declared to shut down places, including educational institutions, to reduce human COVID-19 transmission ${ }^{18}$. More than 1.5 billion enrolled students of all ages worldwide got interruption of education 19, 20 . All levels of Bangladeshi students have experienced the interruption of education for a long time. School closure associated with COVID-19 is longer and more uncertain than other sporadic instances like natural calamity, civil unrest, war, and strikes. Hence, policymakers and educators had to think of some emergency methods to ensure the continuity of education. In the social distancing situation, healthcare and education institutions in many countries started shifting to electronic work (eWork) policy ${ }^{21-23}$. Consequently, online distant teaching-learning education practice has been adopted in different delivery modes to substitute conventional classroom education.

\section{Challenges of Online Education Modalities}

The electronic educational practices during the COVID-19 pandemic are called at different names 
in different countries, notably distance education, e-learning, online education, and school from home. The sudden transition to electronic communication for distant teaching-learning modalities has made the previously established class-teaching approach obsolete. The whole teaching community, including learners, teachers, and parents, is experiencing a great deal of anxiety for shifting from face-to-face to online teaching with limited or no prior exposure in some cases. Other restrictions like self-isolation, lockdown, chances of COVID-19 infection, decreasing family income, job insecurity have impacted a multiple added burden to all the teachinglearning stakeholders. With the uncertainty of human existence in this pandemic, deficiency of technology know-how and its appropriate resources have resulted in anxiety and trauma to students, teachers, and guardians. It has put some bottle-neck pressure on all the concerned allies, especially in resource lagging countries, including Bangladesh.

UGC of Bangladesh has recognized the necessity of online education during the COVID-19 pandemic. The authority has endorsed guidelines to all public and private universities to transit from face-to-face to online teaching. However, most Bangladeshi students and faculty members had no fundamental training and resources to accept the challenges of e-teaching-learning in most university settings. As rarely our teachers and students earned prior exposure to conducting online education. We recognized some inherent barriers of online education at university: weak technical skills, poor infrastructure (scarcity of computers/smartphones for students, poor internet speed, interruption of electricity), unstable institutional strategies, and high internet cost ${ }^{24}$. A typical negative attitude of both teachers and students acts as a barrier to shifting e-education methods. Lack of insufficient technical skills was the first challenge identified in online teaching for university students and faculty. An insufficient computer using and writing skills have provoked a negative attitude, particularly from teachers towards embracing the new e-education system. The lack of technical skills generates confidence that negatively impacts online learning delivery ${ }^{25}$. The students who find difficulty adopting the technical know-how of online education systems may negatively impact their mental health ${ }^{26}$. Online teaching makes students into less-engaged, unattended passive learners. The unengaged students can collect the requisite lecture notes, lecture recordings, study content from the online repository.
E-learning minimizes the possibility of building an excellent mentoring relationship between faculty and students as well. Notably, online education has a severe flaw for subjects where hands-on training and demonstration are imperative. Hands-on training builds students' competence in their professional subjects by increasing the breadth and depth of their learning. One of the challenges of online classes we recognize is the interruption of internet connection either at teachers' or students' end, voice quality we compromise very frequently in our online teaching system. The e-learning system engages students and teachers for a long time in front of the computer screen and upsets social interaction, reducing reallife verbal and nonverbal communication, which are reasonable means of passive learning ${ }^{27}$.

\section{Opportunities of Online Education System}

Besides many challenges, online pedagogy has brought several opportunities to tertiary education systems in developing countries. Online education favors the flexibility of teachers and students for setting lesson plans. Teaching is a lifetime learning process. Online education brings new opportunities for instructors and students to be acquainted with different digital platforms for teaching-learning. The development of electronic communications for university education will be a great addition to the existing conventional systems. The shifting of electronic communication channels develops students' and teachers' instructional skills, learning skills, administrative services, and educational facilities. Adopted digital technology in university education helps to engage all students from suitable remote locations. The system allows teachers to regularly check in with students for feedback on course materials and assignments more conveniently with digital forms and drives. Technology can automate some tedious assessment tasks of instructors, such as keeping track of student attendance, performance, and grading for quizzes. Therefore, integrating technology in the classroom can reduce the amount of time spent on minor tedious tasks.

Technology is an essential life skill for both teachers and students in the current digital world. Being digitally literate is in no way inferior to obtaining isolated technological skills for students' careerism. Creative presentations, learning to search necessary information from reliable internet sources, and maintaining online communication with proper etiquette are vital skills students can learn from their classroom. Real-time e-communication skills from 
mobile technology are a must-have requirement for students for almost any potential career today. Investment for shifting to technology-based education in the universities of developing countries will boost students' achievement for a better return 28. COVID-19 pandemic provides a paradoxical opportunity to developing world's education systems to cope with the generation $\mathrm{Z}$ teaching-learning system of the developed world ${ }^{29}$.

\section{Unlearning, Relearning, and Life-long learning in Education}

Modern teaching methodologies suggest teachers and students in a continuous process oflearning, promoting student engagement, understanding, and supporting life-long learning (LLL) ${ }^{30,31}$. LLL is defined as intentional learning that people engage in throughout their lives for personal and professional fulfilment to improve their life quality ${ }^{32}$. It has been recognized as a critical and comprehensive educational goal in the ever-changing societal and professional demands ${ }^{33}$. In recent years, LLL has emerged as a significant wing of education policy around the globe ${ }^{31,32}$. It enhances the development of a lifelong learning attitude in the students and teachers that would help them adapt and learn throughout their lives in a broad range of situations and from many divergent sources. During the shutdown of all universities and higher education institutions in the COVID-19 pandemic, the authority needs to develop different sustainable education delivery modalities to fulfill the purposes of education in this contemporary world. Shifting the education paradigm requires reconfiguring the institutions, particularly setting a technology framework and training teaching staff with a newly adopted system. It is recognized that learning new things is always tricky for any aged professionals. However, attitudes of unlearning peoples from their existing mindsets, behavior, and methods are challenging for setting new modalities in higher education 34,35 . COVID-19 pandemic has brought the academic world into a time for 'unlearning' old teaching habits and systems that have been useful in the past but may not be a good fit for the present and future. Thus, teachers and other academic staff should embrace the 'cycle of unlearning' timely in the world of uncertainty like COVID-19 to earn more impactful, value-adding pedagogy for their students 36. When teachers' motivation to learn to unlearn and then relearn is set, then teachers' education to new digital technologies in education has become challenging during the COVID-19 pandemic, especially in developing countries 37,38. Besides many inherent challenges, the COVID-19 pandemic has administered profound opportunities to the educational institutions of developing countries to change or revise some of their traditional teaching practices by adopting the current information and communication technologies.

\section{COVID-19 and Paradigm Shift in Education: New Challenges and Prospects}

Education is no longer defined by what a teacher will instruct but rather what a student will learn, understand, and demonstrate. These are transitions from an instruction paradigm to a learning paradigm, in which a teacher's role is that of a coach. The shifting from teacher-centered to student-centered teaching began years back in the developed world via innovative online education programs $39,40$. The COVID-19 pandemic has allowed developing countries to upgrade their teaching-learning styles from teacher-centered to student-centered learning for the modern millennial generation ${ }^{41,42}$.

Key factors that influence these paradigm shifts are restructuring curricular framework, school leadership and organization, modes of instructional design, international partnership in teaching and learning, and international Exchange programs that enhance students' global mobility, employability, and competitiveness ${ }^{43}$. Technology integration into instruction methods of education systems is the single most vital driver to represents a paradigm shift in education systems ${ }^{43,44}$. Effective use of technology in the classroom for the paradigm shift from "teaching" to "learning" requires adequate training to teach staff for technology utilization. Thus, for universities to remain competitive in the new millennium, they must provide adequate technical support and develop cohesive training programs that will assist faculty in integrating technology into instruction.

\section{Conclusion and Recommendations}

The COVID-19 pandemic is an unavoidable disruption; paradoxically, it has brought the opportunity of developing countries to upgrade technology in education to transform online teaching and learning, thus making it a positive learning curve for the global community. University authorities of developing countries should take sufficient initiatives to improve the attitudes and mindsets of their teaching staff to become lifelong learners to adopt any unforeseen situation like the COVID-19 pandemic and uphold their educations to the higher 
high direction. Policymakers and the university authorities should develop the skills and competency of students and teachers in basic skills of digital technologies to prepare for a constantly changing world of work. Education and health are intrinsically linked. Quality education can improve health at individual and societal levels. Developed countries earn multifold and diversified more significant returns of investments from education. The government of developing countries should increase investment in competence development of science, technology, engineering, and mathematics (STEM) education to ensure health, economy, and well-being for the present and future generations.

\section{Conflicts of interest and Funding}

The author declared no conflicts of interest, and the study had no funding.

\section{Acknowledgment}

The author is sincerely thankful to Professor Dr. Mainul Haque for his scholastic suggestions and review inputs for this article.

\section{References}

1. Abrams EM, Szefler SJ. COVID-19 and the impact of social determinants of health. Lancet Respir Med. 2020;8(7):659-661. doi: 10.1016/S22132600(20)30234-4.

2. Marinoni G, Van't Land H, Jensen T. The impact of Covid-19 on higher education around the world. IAU Global Survey Report. 2020. Available at https://www. iau-aiu.net/IMG/pdf/iau_covid19 and he survey report_final may 2020.pdf [Accessed August 08, 2021]
3. Godman B. Combating COVID-19: Lessons learnt particularly among developing countries and the implications. Bangladesh Journal of Medical Science. 2020; 19, S103-S108. https://doi.org/10.3329/bjms. $\underline{\mathrm{v} 19 \mathrm{i} 0.48413}$

4. Huynh TLD. Does culture matter social distancing under the COVID-19 pandemic? Saf Sci. 2020;130:104872. doi: 10.1016/j.ssci.2020.104872.

5. Back A, Tulsky JA, Arnold RM. Communication Skills in the Age of COVID-19. Ann Intern Med. 
2020;172(11):759-760. doi: 10.7326/M20-1376.

6. Whitelaw S, Mamas MA, Topol E, Van Spall HGC. Applications of digital technology in COVID-19 pandemic planning and response. Lancet Digit Health. 2020;2(8):e435-e440. doi: 10.1016/S25897500(20)30142-4.

7. Rashid AA Rashid MRA, Yaman MN, Mohamad I. Teaching Medicine Online During the COVID-19 Pandemic: A Malaysian Perspective. Bangladesh Journal of Medical Science. 2020; 19: S77-S81. https:// doi.org/10.3329/bjms.v19i0.48170.

8. Malik YS, Kumar N, Sircar S, Kaushik R, Bhat S, Dhama K, Gupta P, Goyal K, Singh MP, Ghoshal U, El Zowalaty ME, O R V, Yatoo MI, Tiwari R, Pathak M, Patel SK, Sah R, Rodriguez-Morales AJ, Ganesh B, Kumar P, Singh RK. Coronavirus Disease Pandemic (COVID-19): Challenges and a Global Perspective. Pathogens. 2020;9(7):519. doi: 10.3390/pathogens9070519.

9. Liu YC, Kuo RL, Shih SR. COVID-19: The first documented coronavirus pandemic in history. Biomed $J$. 2020;43(4):328-333. doi: 10.1016/j.bj.2020.04.007.

10. Sohrabi C, Alsafi Z, O’Neill N, Khan M, Kerwan A, AlJabir A, Iosifidis C, Agha R. World Health Organization declares global emergency: A review of the 2019 novel coronavirus (COVID-19). Int J Surg. 2020;76:71-76. doi: 10.1016/j.ijsu.2020.02.034.

11. World Health Organization. COVID-19 weekly epidemiological update, edition 50, 27 July 2021.2021. Available at https://apps.who.int/iris/ handle/10665/343387 [Accessed August 08, 2021]

12. Sarkar SH, Hossain SZ. (2018) Higher Education Systems and Institutions, Bangladesh. In: Teixeira P., Shin J. (eds) Encyclopedia of International Higher Education Systems and Institutions. Springer, Dordrecht. https://doi.org/10.1007/978-94-017-9553-1_499-1 [Accessed August 08, 2021].

13. Kabir AH. Neoliberal hegemony and the ideological transformation of higher education in Bangladesh. Critical Literacy: Theories and Practices. 2012;6(2):215. Available at http://criticalliteracy.freehostia.com/ index.php?journal $=$ criticalliteracy \&page $=$ article \&op =viewFile \& path $\% 5 \mathrm{~B} \% 5 \mathrm{D}=120 \&$ path $\% 5 \mathrm{~B} \% 5 \mathrm{D}=90$ [Accessed August 08, 2021].

14. Ramachandran S. The COVID-19 Catastrophe in Bangladesh. 2020. Available at URL: https://thediplomat. com/2020/04/the-covid-19-catastrophe-in-bangladesh/. [Accessed August 08-2021]

15. World Health Organization. Bangladesh. COVID-19 Situation Report 4. 2020. Available at URL: https:// www.who.int/docs/default-source/searo/bangladesh/ covid-19-who-bangladesh-situation-reports/who-ban- covid-19-sitrep-04.pdf?sfvrsn=69b6d931 8 [Accessed August 08-2021]

16. World Health Organization. Bangladesh Situation. 2021. Available at https://covid19.who.int/region/searo/ country/bd [Accessed August 08-2021]

17. Haque M, Islam S, Iqbal S, Urmi UL, Kamal ZM, Rahman A, Kamal M, Haque M, Jahan I, Islam Z, Hossain MM, Murshid ME, Sefah I, Kurdi A, Godman B. Availability and price changes of potential medicines and equipment for the prevention and treatment of COVID-19 among pharmacy and drug stores in Bangladesh; findings and implications. Bangladesh Journal of Medical Science. 2020; 19, S36-S50. https://doi.org/10.3329/bjms. v19i0.48106.

18. Chowdhury SR, Sunna TC, Sanjoy S. Response to COVID-19 in Bangladesh: Strategies to Resist the Growing Trend of COVID-19 in a Less Restricted Situation. Asia Pac J Public Health. 2020;32(8):471472. doi: 10.1177/1010539520951689.

19. Viner RM, Russell SJ, Croker H, Packer J, Ward J, Stansfield C, Mytton O, Bonell C, Booy R. School closure and management practices during coronavirus outbreaks including COVID-19: a rapid systematic review. Lancet Child Adolesc Health. 2020;4(5):397404. doi: 10.1016/S2352-4642(20)30095-X.

20. Bozkurt A, Jung I, Xiao J, Vladimirschi V, Schuwer R, Egorov $\mathrm{G}$, et al. A global outlook to the interruption of education due to COVID-19 pandemic: Navigating in a time of uncertainty and crisis. Asian Journal of Distance Education. 2020;15(1):1-126.

21. Teele SA, Sindelar A, Brown D, Kane DA, Thatte N, Williams RJ, Gueverra J, Wolbrink TA. Online education in a hurry: Delivering pediatric graduate medical education during COVID-19. Prog Pediatr Cardiol. 2021;60:101320. doi: 10.1016/j.ppedcard.2020.101320.

22. He S, Lai D, Mott S, Little A, Grock A, Haas MRC, Chan TM. Remote e-Work and Distance Learning for Academic Medicine: Best Practices and Opportunities for the Future. J Grad Med Educ. 2020;12(3):256-263. doi: 10.4300/JGME-D-20-00242.1.

23. Brady AK, Pradhan D. Learning without Borders: Asynchronous and Distance Learning in the Age of COVID-19 and Beyond. ATS Sch. 2020;1(3):233-242. doi: 10.34197/ats-scholar.2020-0046PS.

24. Khan MSH, Hasan M, Clement CK. Barriers to the introduction of ICT into education in developing countries: The example of Bangladesh. International Journal of instruction. 2012;5(2).

25. O’Doherty D, Dromey M, Lougheed J, Hannigan A, Last $\mathrm{J}$, McGrath D. Barriers and solutions to online learning in medical education - an integrative review. $B M C \mathrm{Med}$ 
Bangladesh Journal of Medical Science, Vol : 20 Special Issue on Covid19, 2021

Educ. 2018;18(1):130. doi: 10.1186/s12909-018-12400 .

26. Costello E, Corcoran MA, Barnett JS, Birkmeier $\mathrm{MC}$, Cohn R, Ekmekci $\mathrm{O}$, et al. Information and communication technology to facilitate learning for students in the health professions: Current uses, gaps, and future directions. Online learning: Official Journal of the Online Learning Consortium. 2014; 18(4). DOI: 10.24059/olj.v18i4.512

27. Knapp ML, Hall JA, Horgan TG. Nonverbal communication in human interaction, Eight Edition: Wadsworth Cengage Learning; Boston, Massachusetts, 2021.

28. Kazi RNA, El Kashif MML, Kolhar M. A comparative study of learning outcomes between video-based and traditional lecture-based teaching in physiology. Bangladesh Journal of Medical Science. 2021;20(4):8339. https://doi.org/10.3329/bjms.v20i4.54142

29. Seemiller C, Grace M. Generation Z: Educating and engaging the next generation of students. About Campus. 2017;22(3):21-6. https://doi.org/10.1002/abc.21293

30. Candy PC. Reaffirming a proud tradition: Universities and lifelong learning. Active Learning in Higher Education. 2000;1(2):101-25. https://doi.org/10.1177/1 469787400001002002

31. Medel-Añonuevo C, Ohsako T, Mauch W. Revisiting Lifelong Learning for the 21st Century. 2001. Available at https://files.eric.ed.gov/fulltext/ED469790.pdf [Accessed August 08, 2021]

32. Dunlap JC, Grabinger S. Preparing students for lifelong learning: A review of instructional features and teaching methodologies. Performance Improvement Quarterly. 2003;16(2):6-25. https://doi. org/10.1111/j.1937-8327.2003.tb00276.x

33. Edwards R, Usher R. Lifelong learning: a postmodern condition of education? Adult Education Quarterly. 2001;51(4):273-87. https://doi. org/10.1177/07417130122087296

34. McWilliam E, Carey G, Draper P, Lebler D. Learning and unlearning: New challenges for teaching in conservatories. Australian Journal of Music Education. 2006; 1: 25-31. Available at https://eprints.qut.edu. au/22021/ [Accessed August 08, 2021]

35. Cochran-Smith M. Learning and unlearning: The education of teacher educators. Teaching and Teacher
Education. 2003;19(1):5-28. https://doi.org/10.1016/ $\underline{\mathrm{S} 0742-051 \mathrm{X}(02) 00091-4}$

36. McWilliam E. Unlearning how to teach. Innovations in Education and Teaching International. 2008;45(3):2639. https://doi.org/10.1080/14703290802176147

37. Fernandes AC, Gattolin SRB. Learning to Unlearn, and then Relearn: Thinking about Teacher Education within the COVID-19 Pandemic Crisis. Revista Brasileira de Linguística Aplicada. 2021;21:521-46. http://dx.doi. org/10.1590/1984-6398202117277

38. Atuahene S, Kong Y, Bentum-Micah G. Covid-19 pandemic, economic loses and education sector management. Quantitative Economics and Management Studies. 2020;1(3):103-9. https://doi. org/10.35877/454RI.qems162

39. Berry B. The Teachers of 2030: Creating a StudentCentered Profession for the 21st Century. Center for Teaching Quality. 2010. Available at https://files.eric. ed.gov/fulltext/ED509721.pdf [Accessed August 08, 2021]

40. Robinson S, Neergaard H, Tanggaard L, Krueger N. New horizons in entrepreneurship: from teacher-led to student-centered learning. Education+ training. 2016; 58 (7/8). https://doi.org/10.1108/ET-03-2016-0048

41. Vijayaratnam P, Rusly NHM, Sivarajah A. The Impact Of The Covid-19 Pandemic On Teaching And Learning: Voices Of Faculty. International Journal of Education and Pedagogy. 2020;2(4):339-51. http://myjms.mohe. gov.my/index.php/ijeap

42. Zhu X, Liu J. Education in and After Covid-19: Immediate Responses and Long-Term Visions. Postdigital Science and Education. 2020;1-5. doi:10.1007/s42438-02000126-3.

43. Rogers DL. A paradigm shift: Technology integration for higher education in the new millennium. AACE Review (formerly AACE Journal). 2000;1(13):19-33.

44. Rodney $\mathrm{BD}$. Understanding the paradigm shift in education in the twenty-first century: The role of technology and the Internet of Things. Worldwide Hospitality and Tourism Themes. 2020; 12 (1): 35-47. doi; 10.1108/WHATT-10-2019-0068 